\title{
PENGARUH RSNI 1726:2018 BERDASARKAN PETA GEMPA INDONESIA 2017 TERHADAP DESAIN BEBAN GEMPA SEISMIK DI KALIMANTAN SELATAN
}

\author{
Eka Purnamasari $^{1}$ \\ ${ }^{1}$ Jurusan Teknik Sipil, Fakultas Teknik Universitas Islam Kalimantan MAB. Jl. Adhiyaksa No. 2, \\ Kayu Tangi, Kota Banjarmasin, Kalimantan Selatan 70123 Indonesia
}

\begin{abstract}
ABSTRAK
Berdasarkan Peta Gempa Indonesia 2017 dan ASCE 7-16 maka disusunlah Rancangan Peraturan Gempa Indonesia RSNI 1726:2018. Sesar Tarakan, sesar Mangkalihat, dan sesar Meratus merupakan tiga zona sesar utama di pulau kalimantan. Sesar yang berada disekitar Kalimantan Selatan yaitu sesar meratus dengan arah NE-SW yang dikenal juga sebagai zona sesar anjak. Sesar-sesar tersebut memiliki panjang lebih dari $100 \mathrm{~km}$ yang dapat berpotensi menimbulkan gempa dengan magnitudo 7.

Sebagai bahan penelitian maka dipilihlah 14 kota besar di Kalimantan Selatan yang berada dizona gempa yang berbeda sesuai dengan Peta Gempa Indonesia 2017. Berdasarkan RSNI 1726:2018 terdapat penetapan nilai Koefisien Situs Fa dan Fv yang baru, dimana hal tersebut mempengaruhi besarnya Spektrum Respons Desain dan Kategori Desain Seismik.

Terjadi penurunan rasio nilai Ss pada Kab. Tabalong dan peningkatan nilai Ss terbesar pada daerah pegunungan meratus dan Kab. Tapin. Pada Spektrum Respons Perioda Pendek 0,2 detik (SDS) pada semua kota di kalimantan selatan terjadi penurunan rasio berdasarkan kelas situs, dengan nilai kelas situs tanah keras (SC) lebih besar dari kelas situs tanah lunak (SE). Sedangkan sebaliknya dari Spektrum Respons Perioda 1-detik (SD1) terjadi peningkatan rasio berdasarkan kelas situs, dengan nilai kelas situs tanah lunak (SE) lebih besar dari pada kelas situs tanah keras (SC). Struktur bangunan dengan kategori resiko IV didapati memiliki kategori desain seismik tertinggi yaitu KDS D Pada Situs Tanah Keras (Sc) terjadi pada daerah yang berada dalam peta zona gempa Ss senilai 0,3 s.d 0,4g; KDS D Pada Situs Tanah Sedang(SD) terjadi pada daerah yang berada dalam peta zona gempa Ss senilai 0,25 s.d 0,4g; KDS D Pada Situs Tanah Lunak (SE) terjadi pada daerah yang berada dalam peta zona gempa Ss senilai 0,05 s.d 0,4g.
\end{abstract}

Kata kunci: beban gempa seismik, RSNI 1726:2018, peta gempa Indonesia 2017, kategori desain seismik, Kalimantan Selatan

\section{PENDAHULUAN}

Sesar Tarakan, sesar Mangkalihat, dan sesar Meratus merupakan tiga zona sesar utama di pulau kalimantan sebagaimana ditunjukkan pada Gambar 1. Sesar-sesar tersebut memiliki panjang lebih dari $100 \mathrm{~km}$ yang dapat berpotensi menimbulkan gempa dengan magnitudo 7. Sesar yang berada disekitar Kalimantan Selatan yaitu sesar meratus dengan arah NE-SW yang dikenal juga sebagai zona sesar anjak. Sesar Mangkalihat yang berupa sesar mendatar, diidentifikasi di pantai timur Pulau Kalimantan.
Sesar mendatar Tarakan dapat dikenali di bagian utara pulau ini yang terbentang mulai dari daratan sampai menerus ke lepas pantai. Kalimantan merupakan area di Indonesia yang memiliki seismisitas paling rendah, dimana seismisitas di Kalimantan lebih didominasi oleh aktivitas sesar dengan kedalaman gempa kurang dari $30 \mathrm{~km}$. Pada tanggal 20 Desember 2015, terjadi gempa dengan magnitudo 6 di Tarakan yang berdasarkan solusi GCMT diakibatkan oleh aktivitas sesar geser.

Correspondence: Eka Purnamasari

Email: eka.ftsuniska@gmail.com 

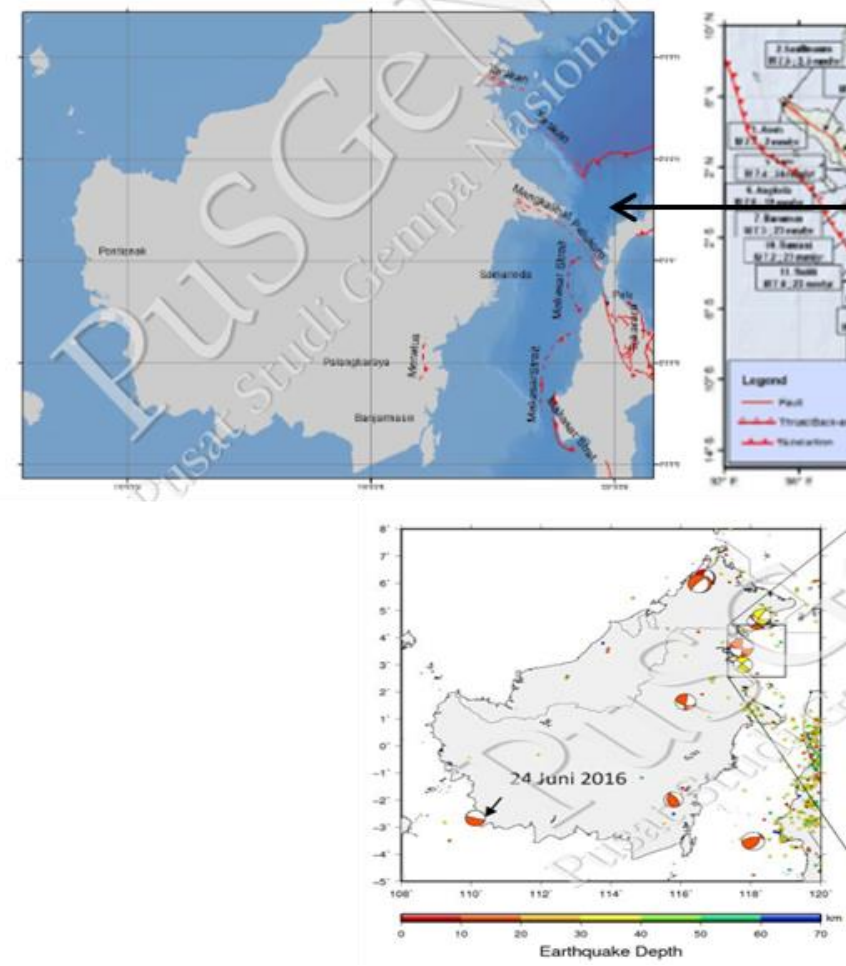

Gambar 1. Sesar Aktif dan Distribusi di Kalimantan Selatan

Gempa ini diikuti oleh aftershock dengan magnitudo mencapai lebih dari 4 yang juga diakibatkan oleh aktivitas sesar geser seperti pada gambar 1. Selain itu, pada tanggal 24 Juni 2016 juga terjadi gempa dengan magnitudo 5,1 di barat daya Kalimantan yang juga diakibatkan oleh sesar di darat.

Dipilih 14 kota besar yang dianggap dapat mewakili seluruh wilayah Kalimantan Selatan sebagai sampel untuk memperlihatkan sejauh mana perbedaan spektrum respons desainnya menurut RSNI 1726:2018 dan peta gempa 2017. Penelitian ini menyajikan pengamatan pengaruh peta gempa 2017 terhadap kategori desain seismik dan kondisi spektrum respons desain untuk perioda pendek dan 1 detik di kelas situs Tanah Keras (SC), Tanah Sedang (SD) dan Tanah Lunak (SE).

\section{METODE PENELITIAN}

\subsection{Spektrum Respons Desain}

Secara prinsip, proses pembuatan Spektrum Respons Desain menurut RSNI
1726:2018 atau ASCE 7-16 amat sederhana. Dari peta MCER untuk perioda pendek $(0.2$ detik) dan perioda 1-detik, dihasilkan nilai percepatan batuan dasar SS dan S1, yang kemudian dikalikan dengan faktor amplifikasi seismic (Koefisien situs) $\mathrm{Fa}$ dan $\mathrm{Fv}$ menghasilkan parameter respons percepatan spektral yang sesuai dengan kelas situs tanah, SMS dan SM1. Besarnya percepatan respons spektral desain pada perioda pendek, SDS, dan pada perioda 1-detik, SD1, adalah 2/3 dari nilai parameter respons percepatan spectral tersebut.

Sesuai dengan ketentuan dalam ASCE 7-16, peta percepatan spektrum respons gempa maksimum yang dipertimbangkan berbasis pada risiko (MCER) dengan redaman 5\% dan kriteria $1 \%$ kemungkinan bangunan runtuh dalam 50 tahun, yang telah disesuaikan untuk kelas situs tanah antara SB dan SC, untuk perioda pendek (0.2 detik) pada Gambar 2 (a) dan perioda 1-detik, yang diperlihatkan dalam Gambar 2 (b), dikembangkan berdasarkan peta hazard dengan probabilitas terlampaui $2 \%$ dalam 50 tahun (perioda ulang gempa 2,475 tahun) yang disusun oleh Tim Pusat Studi Gempa Nasional dalam Peta Sumber dan Bahaya Gempa Tahun 2017.

Jurnal Teknologi Berkelanjutan (Sustainable Technology Journal) Vol. 7 No. 2 (2018) pp. 73 - 81 


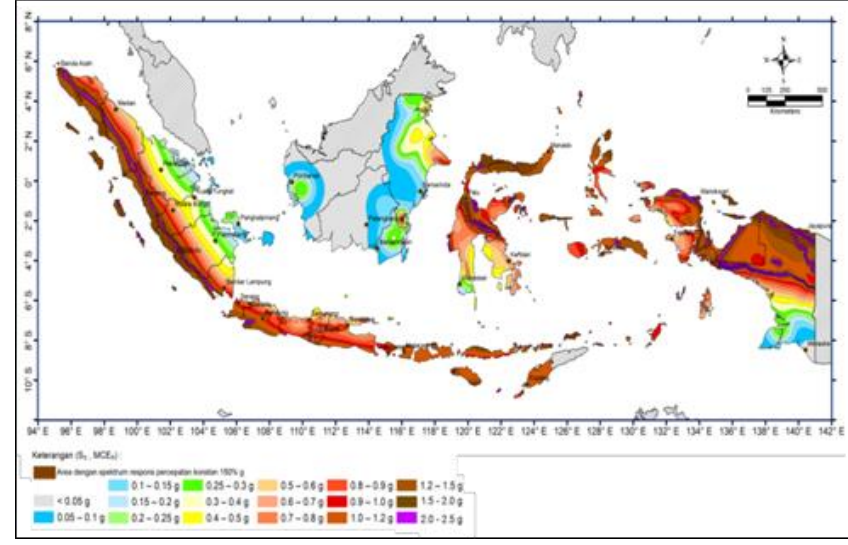

(a)

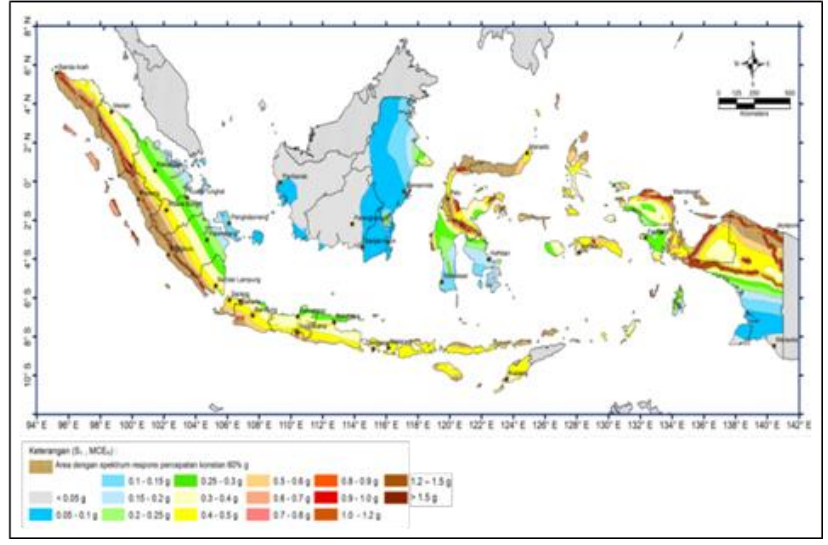

(b)

Gambar 2. (a) Peta Percepatan Spektrum Respons 0.2 detik MCER (Redaman 5\% - Kelas Situs Tanah SB/SC). (b) Peta Percepatan Spektrum Respons 1-detik MCER (Redaman 5\% Kelas Situs Tanah SB/SC).

2.2 Koefisien Situs $F_{a}$ dan $F_{v}$

Nilai faktor amplifikasi percepatan atau koefisien situs $\mathrm{Fa}$ dan Fv dalam RSNI 1726:2018 mengadopsi hasil studi dari
Pacific Earthquake Engineering Research (PEER), seperti yang diperlihatkan dalam Tabel 1 dan Tabel 2.

Tabel 1. Koefisien Situs $F_{a}$ RSNI 1726:2018

\begin{tabular}{ccccccc}
\hline \multirow{2}{*}{$\begin{array}{c}\text { Kelas } \\
\text { Situs }\end{array}$} & \multicolumn{5}{c}{ Parameter Percepatan Respons Spektral MCER pada Perioda Pendek (0.2 detik ) } \\
& $S_{S} \leq 0.25$ & $S_{S}=0.5$ & $S_{S}=0.75$ & $S_{S}=1.0$ & $S_{S}=1.25$ & $S_{S} \geq 1.5$ \\
\hline SA & 0,8 & 0,8 & 0,8 & 0,8 & 0,8 & 0,8 \\
SB & 0,9 & 0,9 & 0,9 & 0,9 & 0,9 & 0,9 \\
SC & 1,3 & 1,3 & 1,2 & 1,2 & 1,2 & 1,2 \\
SD & 1,6 & 1,4 & 1,2 & 1,1 & 1 & 1 \\
SE & 2,4 & 1,7 & 1,3 & 1,1 & 0,9 & 0,8 \\
SF & Situs & Situs & Situs & Situs & Situs & Situs \\
& Spesifik & Spesifik & Spesifik & Spesifik & Spesifik & Spesifik \\
\hline
\end{tabular}

Tabel 2. Koefisien Situs $F_{v}$ RSNI 1726:2018

\begin{tabular}{ccccccc}
\hline \multirow{2}{*}{$\begin{array}{c}\text { Kelas } \\
\text { Situs }\end{array}$} & \multicolumn{5}{c}{ Parameter Percepatan Respons Spektral MCER pada Perioda 1 detik } \\
& $S_{1} \leq 0.1$ & $S_{1}=0.2$ & $S_{1}=0.3$ & $S_{1}=0.4$ & $S_{1}=0.5$ & $S_{1} \geq 0.6$ \\
\hline SA & 0,8 & 0,8 & 0,8 & 0,8 & 0,8 & 0,8 \\
SB & 0,8 & 0,8 & 0,8 & 0,8 & 0,8 & 0,8 \\
SC & 1,5 & 1,5 & 1,5 & 1,5 & 1,5 & 1,4 \\
SD & 2,4 & 2,2 & 2 & 1,9 & 1,8 & 1,7 \\
SE & 4,2 & 3,3 & 2,8 & 2,4 & 2,2 & 2 \\
SF & Situs & Situs & Situs & Situs & Situs & Situs \\
& Spesifik & Spesifik & Spesifik & Spesifik & Spesifik & Spesifik \\
\hline
\end{tabular}




\section{HASIL DAN PEMBAHASAN}

Nilai spectrum respon desain perioda pendek 0,2 detik menurut RSNI 1726:2018 (Gambar 3) di Kab. Tabalong mengalami penurunan dengan nilai 0,675 , enam kota (Banjarmasin, Banjarbaru, Kabupaten Tanah Laut, Kabupaten Banjar, Kab. Hulu Sungai Utara) tidak mengalami perubahan, lima kota (Kab. Tanah bumbu, Kotabaru, Barito Kuala, HSS, dan HST) mengalami kenaikan dengan rasio antara 1,053 - 1,261 dan dua kota (Pegunungan Meratus dan Kab. Tapin) mengalami kenaikan terbesar yaitu dengan rasio antara 1,600 - 1,667 dibandingkan dengan nilai spektrum respons desain Ss menurut SNI 1726:2012. Sedangkan dari peta percepatan batuan dasar periode pendek 1 detik (S1) tahun 2017, seluruh daerah provinsi kalimantan selatan masuk pada daerah spektrum gempa berkisar dari $0,05 \mathrm{~g}$ sampai dengan $0,1 \mathrm{~g}$. Pada tabel 3 menyajikan nilai $S s$ dan $S_{1}$ pada empat belas kabupaten/kota yang dianggap mewakili kotakota diseluruh Kalimantan Selatan.

Nilai spectrum respon desain perioda pendek 1 detik menurut RSNI 1726:2018 (Gambar 4) di sepuluh kota (Kabupaten Banjar, Kab. Hulu Sungai Utara, Kotabaru (Pulau Laut), Kab. Tapin, Kab Tanah Bumbu, Kab. Hulu Sungai Selatan, Kab. Kotabaru, Kab. Hulu Sungai Utara, Kab. Tabalong, dan Pegunungan Meratus) tidak mengalami perubahan, Kab. Tanah Laut mengalami kenaikan dengan rasio 1,250, Kab. Barito Kuala mengalami kenaikan dengan rasio 1,500 dan dua kota (Banjarmasin dan Banjarbaru) mengalami kenaikan dengan rasio 1,667 .

Tabel 3. Parameter Percepatan Respons Spektral Perioda Pendek dan Perioda 1 detik berdasarkan peta $\mathrm{MCE}_{\mathrm{R}}$ di Kalimantan Selatan

\begin{tabular}{llcccccc}
\hline NO & \multicolumn{1}{c}{ KOTA } & $\begin{array}{c}\text { PETA } \\
\text { GEMPA }\end{array}$ & $\begin{array}{c}\text { PETA } \\
\text { GEMPA }\end{array}$ & Rasio & $\begin{array}{c}\text { PEMA } \\
\text { GEMP }\end{array}$ & $\begin{array}{c}\text { PETA } \\
\text { GEMPA }\end{array}$ & Rasio \\
& & $\mathbf{2 0 1 1}$ & $\mathbf{2 0 1 7}$ & & $\mathbf{2 0 1 1}$ & $\mathbf{2 0 1 7}$ & \\
\hline 1 & Banjarmasin & 0,060 & 0,060 & 1,000 & 0,03 & 0,05 & 1,667 \\
2 & Banjarbaru & 0,055 & 0,055 & 1,000 & 0,03 & 0,05 & 1,667 \\
3 & Kabupaten Tanah Laut & 0,050 & 0,050 & 1,000 & 0,04 & 0,05 & 1,250 \\
4 & Kabupaten Banjar & 0,120 & 0,120 & 1,000 & 0,06 & 0,06 & 1,000 \\
5 & Kab. Barito Kuala & 0,090 & 0,110 & 1,222 & 0,04 & 0,06 & 1,500 \\
6 & Kotabaru (Pulau Laut) & 0,140 & 0,140 & 1,000 & 0,06 & 0,06 & 1,000 \\
7 & Kab. Tapin & 0,120 & 0,200 & 1,667 & 0,07 & 0,07 & 1,000 \\
8 & Kab Tanah Bumbu & 0,190 & 0,200 & 1,053 & 0,07 & 0,07 & 1,000 \\
9 & Kab. Hulu Sungai Selatan & 0,200 & 0,250 & 1,250 & 0,08 & 0,08 & 1,000 \\
10 & Kab Hulu Sungai Tengah & 0,230 & 0,290 & 1,261 & 0,09 & 0,09 & 1,000 \\
11 & Kab. Kotabaru & 0,250 & 0,300 & 1,200 & 0,09 & 0,09 & 1,000 \\
12 & Kab. Hulu Sungai Utara & 0,280 & 0,280 & 1,000 & 0,09 & 0,09 & 1,000 \\
13 & Kab. Tabalong & 0,400 & 0,270 & 0,675 & 0,09 & 0,09 & 1,000 \\
14 & Pegunungan Meratus & 0,250 & 0,400 & 1,600 & 0,09 & 0,09 & 1,000 \\
\hline
\end{tabular}


Eka Purnamasari

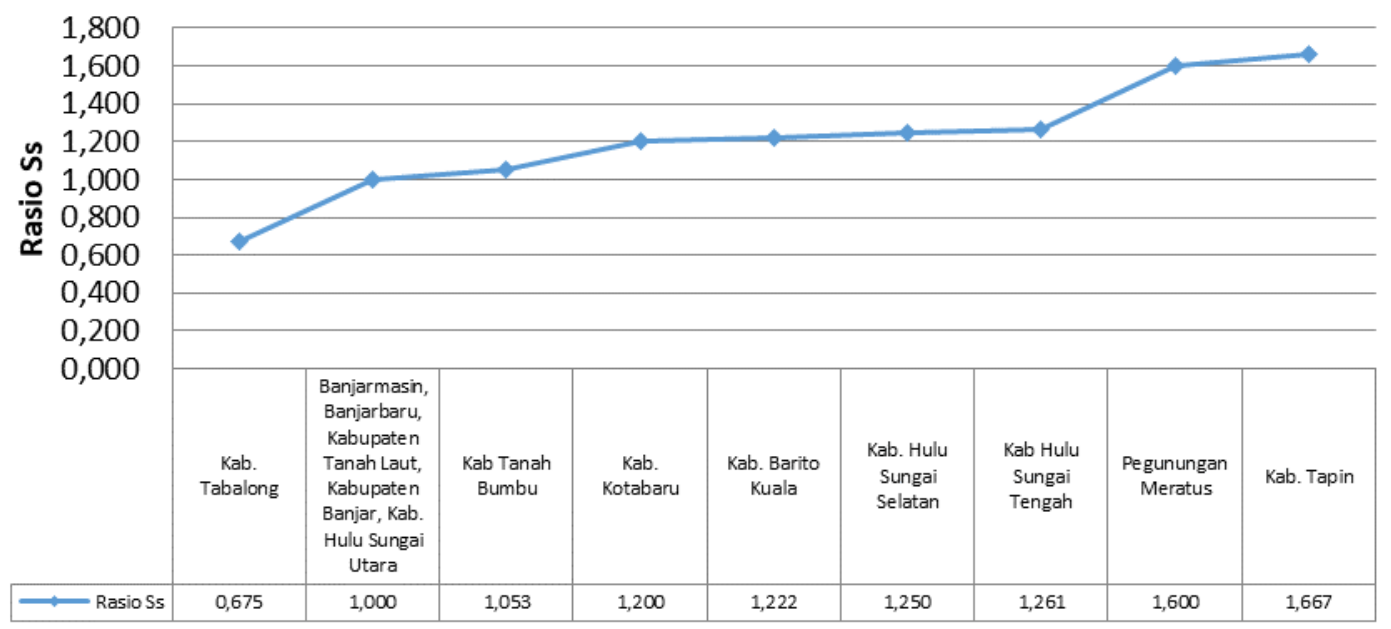

Gambar 3. Rasio Parameter Percepatan Respons Spektral Perioda Pendek $\left(\mathrm{S}_{\mathrm{S}}\right)$

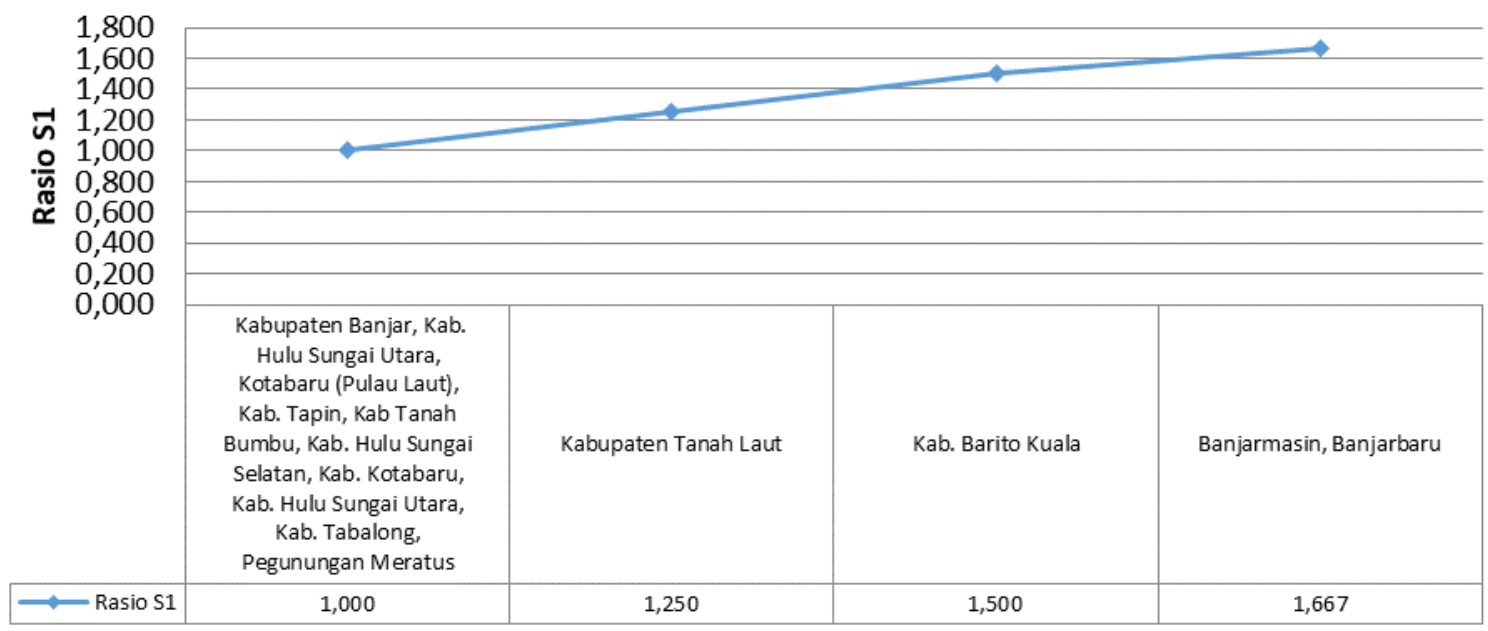

Gambar 4. Rasio Parameter Percepatan Respons Spektral Perioda 1 detik $\left(\mathrm{S}_{1}\right)$

Nilai Parameter Percepatan Respons Spektral Perioda pendek 0,2 detik $\left(\mathrm{S}_{\mathrm{DS}}\right)$ menurut RSNI 1726:2018 berdasarkan nilai $\mathrm{F}_{\mathrm{A}}$, kelas situs SC, SD dan SE (Gambar 6) di Kab. Tabalong mengalami penurunan dengan rasio 0,722-0,783, enam kota (Banjarmasin, Banjarbaru, Kabupaten Tanah Laut, Kabupaten Banjar, Kab. Hulu Sungai Utara) mengalami perubahan dengan rasio 0,9601,083, lima kota (Kab. Tanah bumbu, Kotabaru, Barito Kuala, HSS, dan HST) mengalami kenaikan dengan rasio antara 1,085-1,366 dan dua kota (Pegunungan Meratus dan Kab. Tapin) mengalami kenaikan terbesar yaitu dengan rasio antara 1,267-1,806 dibandingkan dengan nilai spektrum respons desain SDS menurut SNI 1726:2012.

Nilai Parameter Percepatan Respons Spektral Perioda 1 detik menurut RSNI 1726:2018 berdasarkan nilai $F_{s}$, kelas situs
SC, SD dan SE (Gambar 5) di sepuluh kota (Kabupaten Banjar, Kab. Hulu Sungai Utara, Kotabaru (Pulau Laut), Kab. Tapin, Kab Tanah Bumbu, Kab. Hulu Sungai Selatan, Kab. Kotabaru, Kab. Hulu Sungai Utara, Kab. Tabalong, dan Pegunungan Meratus) mengalami perubahan dengan rasio 0,8821,200, Kab. Tanah Laut mengalami kenaikan dengan rasio 1,103-1,500, Kab. Barito Kuala mengalami kenaikan dengan rasio 1,3241,800 dan dua kota (Banjarmasin dan Banjarbaru) mengalami kenaikan dengan rasio 1,471-2,000. 
Eka Purnamasari

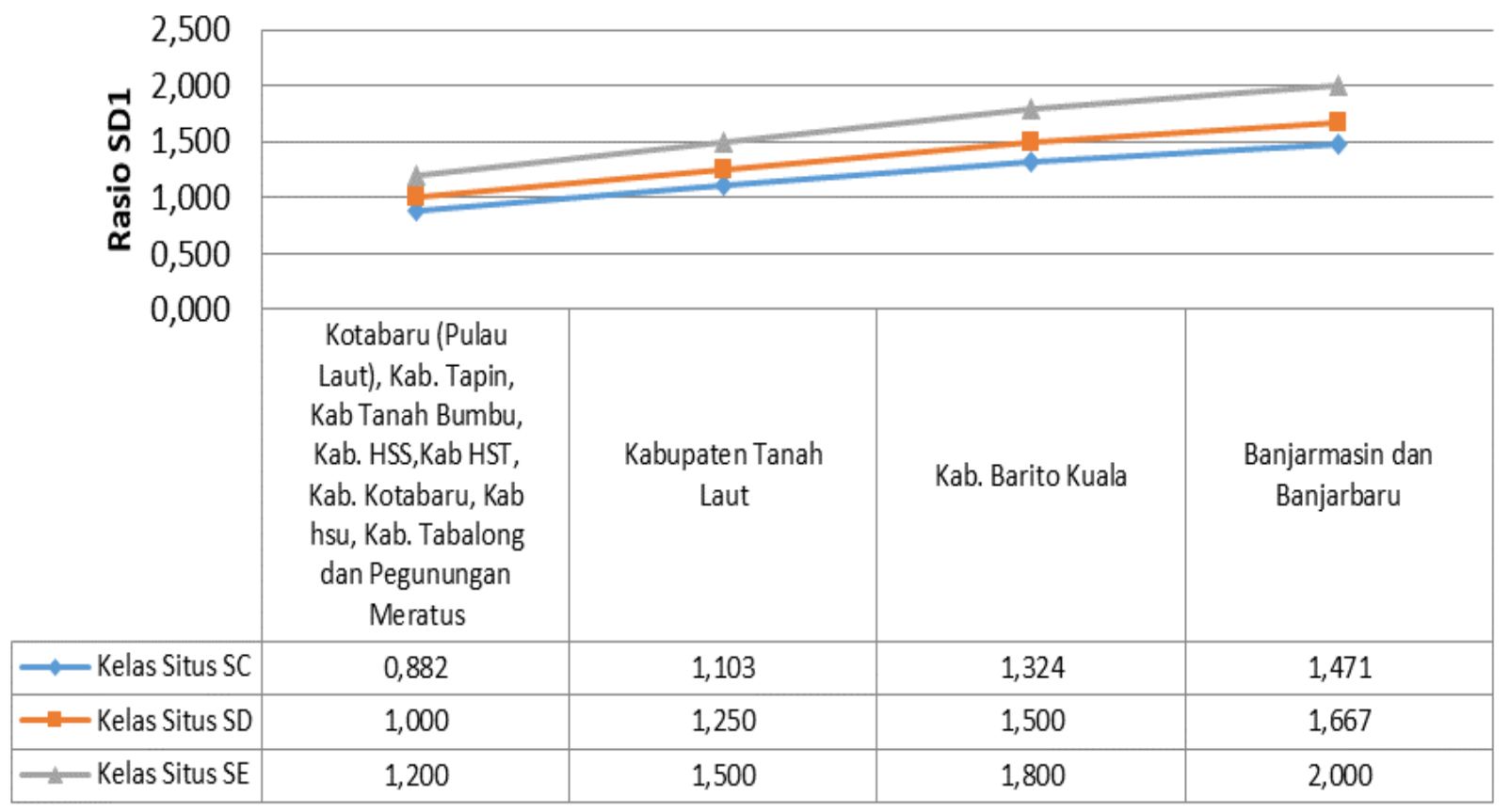

Gambar 5. Rasio Spektrum Respons Perioda 1-detik $\left(S_{D 1}\right)$

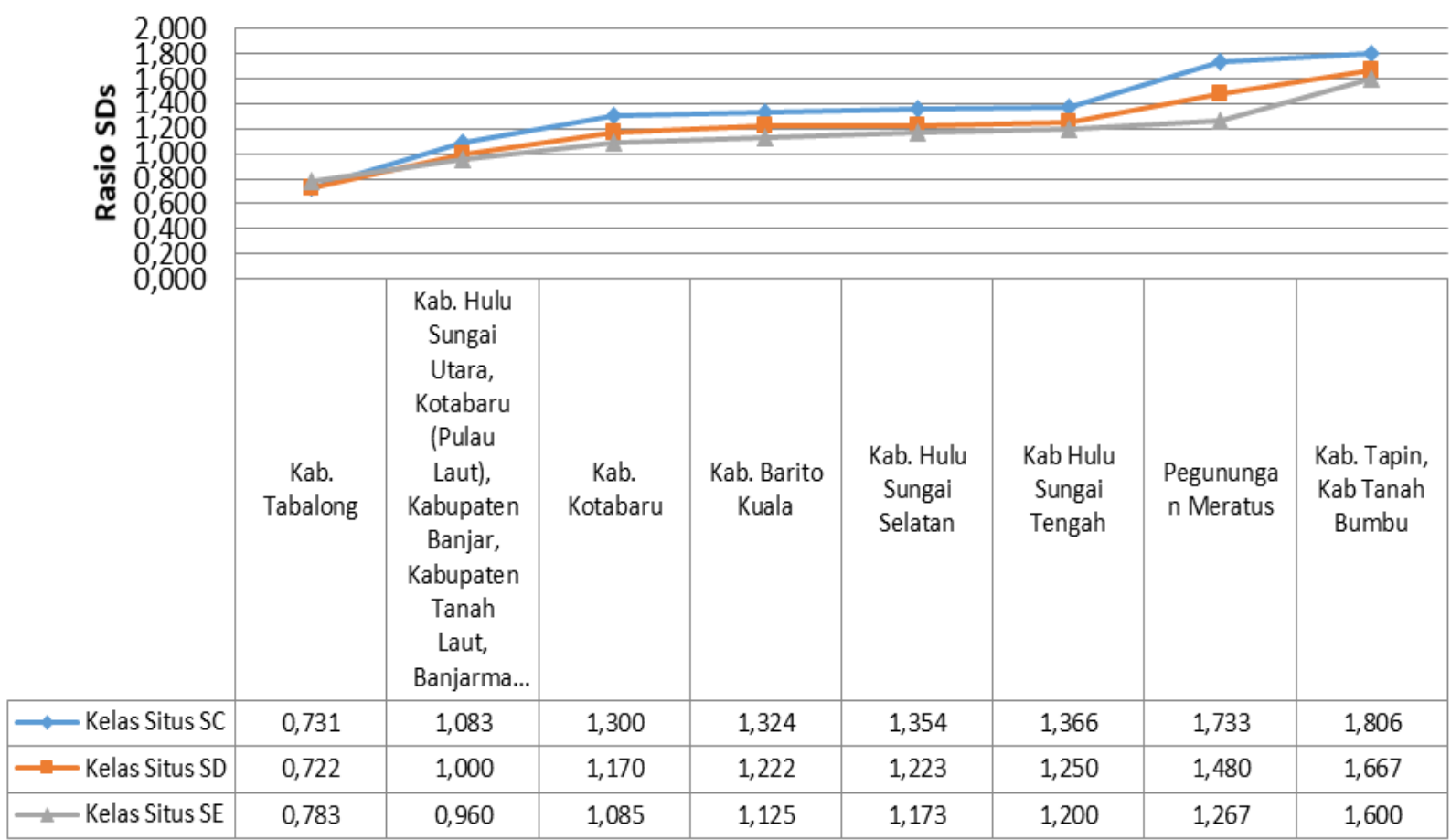

Gambar 6. Rasio Spektrum Respons Perioda Pendek $\left(S_{D S}\right)$ Berdasarkan Kelas Situs

Setelah mendapatkan $\mathrm{S}_{\mathrm{DS}}$ dan $\mathrm{S}_{\mathrm{D} 1}$ pada semua jenis struktur ditentukan Kategori Desain Seismik (KDS) yang dinyatakan dalam huruf A hingga F. Struktur dengan risiko gempa paling kecil dikategorikan ke dalam KDS A, sedangkan struktur dengan tingkat risiko gempa paling tinggi dikategorikan ke dalam KDS F. Pada Tabel 4 dan Tabel 5 menunjukkan kesimpulan hasil perbandingan antara KDS berdasarkan $\mathrm{S}_{\mathrm{DS}}$ dan KDS berdasarkan $\mathrm{S}_{\mathrm{D} 1}$, dari perbandingan tersebut diambil nilai KDS yang paling tinggi. 
Tabel 4. Kategori Desain Seismik Berdasarkan $S_{D S}$ dan $S_{D 1}$ untuk Kategori Resiko I dan II di Kalimantan Selatan

\begin{tabular}{|c|c|c|c|c|c|c|c|c|c|c|c|c|c|}
\hline \multirow{3}{*}{ NO. } & \multirow[t]{3}{*}{ KOTA } & \multicolumn{6}{|c|}{$\begin{array}{l}\text { KATEGORI DESAIN SEISMIK } \\
\text { SNI 1726-2012 }\end{array}$} & \multicolumn{6}{|c|}{$\begin{array}{c}\text { KATEGORI DESAIN SEISMIK } \\
\text { RSNI 1726-2018 }\end{array}$} \\
\hline & & \multicolumn{3}{|c|}{$\begin{array}{l}\text { Kategori Resiko I } \\
\quad(I e=1,0)\end{array}$} & \multicolumn{3}{|c|}{$\begin{array}{l}\text { Kategori } \\
\text { Resiko II }\end{array}$} & \multicolumn{3}{|c|}{$\begin{array}{l}\text { Kategori Resiko I } \\
\quad(\mathbf{I e}=\mathbf{1 , 0 )}\end{array}$} & \multicolumn{3}{|c|}{$\begin{array}{l}\text { Kategori } \\
\text { Resiko II }\end{array}$} \\
\hline & & SC & SD & SE & SC & SD & SE & SC & SD & SE & SC & SD & SE \\
\hline 1 & Banjarmasin & $\mathrm{A}$ & $\mathrm{A}$ & $\mathrm{B}$ & A & $\mathrm{A}$ & $\mathrm{B}$ & $\mathrm{A}$ & $\mathrm{B}$ & $\mathrm{C}$ & $\mathrm{A}$ & $\mathrm{B}$ & $\mathrm{C}$ \\
\hline 2 & Banjarbaru & A & A & B & A & A & B & A & B & $\mathrm{C}$ & A & B & $\mathrm{C}$ \\
\hline 3 & Kabupaten Tanah Laut & A & A & B & $A$ & A & $\mathrm{B}$ & A & B & $\mathrm{C}$ & A & B & $\mathrm{C}$ \\
\hline 4 & Kabupaten Banjar & B & B & $\mathrm{C}$ & $\mathrm{B}$ & B & $\mathrm{C}$ & A & B & $\mathrm{C}$ & A & B & $\mathrm{C}$ \\
\hline 5 & Kab. Barito Kuala & A & A & B & $\mathrm{A}$ & A & $\mathrm{B}$ & A & B & $\mathrm{C}$ & A & B & $\mathrm{C}$ \\
\hline 6 & Kotabaru (Pulau Laut) & B & B & $\mathrm{C}$ & B & B & $\mathrm{C}$ & A & B & $\mathrm{C}$ & A & B & $\mathrm{C}$ \\
\hline 7 & Kab. Tapin & B & B & $\mathrm{C}$ & B & B & $\mathrm{C}$ & B & B & $\mathrm{C}$ & $\mathrm{B}$ & B & $\mathrm{C}$ \\
\hline 8 & Kab Tanah Bumbu & B & B & $\mathrm{C}$ & $\mathrm{B}$ & $\mathrm{B}$ & $\mathrm{C}$ & B & B & $\mathrm{C}$ & $\mathrm{B}$ & B & $\mathrm{C}$ \\
\hline 9 & Kab. Hulu Sungai Selatan & B & $\mathrm{C}$ & $\mathrm{C}$ & $\mathrm{B}$ & $\mathrm{C}$ & $\mathrm{C}$ & B & B & $\mathrm{D}$ & $\mathrm{B}$ & B & $\mathrm{D}$ \\
\hline 10 & Kab Hulu Sungai Tengah & B & $\mathrm{C}$ & $\mathrm{D}$ & B & $\mathrm{C}$ & $\mathrm{D}$ & B & $\mathrm{C}$ & $\mathrm{D}$ & $\mathrm{B}$ & $\mathrm{C}$ & $\mathrm{D}$ \\
\hline 11 & Kab. Kotabaru & B & $\mathrm{C}$ & $\mathrm{D}$ & $\mathrm{B}$ & $\mathrm{C}$ & $\mathrm{D}$ & B & $\mathrm{C}$ & $\mathrm{D}$ & B & $\mathrm{C}$ & $\mathrm{D}$ \\
\hline 12 & Kab. Hulu Sungai Utara & B & $\mathrm{C}$ & $\mathrm{D}$ & $\mathrm{B}$ & $\mathrm{C}$ & $\mathrm{D}$ & B & $\mathrm{C}$ & $\mathrm{D}$ & B & $\mathrm{C}$ & $\mathrm{D}$ \\
\hline 13 & Kab. Tabalong & B & $\mathrm{C}$ & $\mathrm{D}$ & $\mathrm{B}$ & $\mathrm{C}$ & $\mathrm{D}$ & B & $\mathrm{C}$ & $\mathrm{D}$ & $\mathrm{B}$ & $\mathrm{C}$ & $\mathrm{D}$ \\
\hline 14 & Pegunungan Meratus & $\mathrm{B}$ & $\mathrm{C}$ & $\mathrm{D}$ & $\mathrm{B}$ & $\mathrm{C}$ & $\mathrm{D}$ & $\mathrm{C}$ & $\mathrm{C}$ & $\mathrm{D}$ & $\mathrm{C}$ & $\mathrm{C}$ & $\mathrm{D}$ \\
\hline
\end{tabular}

Tabel 5. Kategori Desain Seismik Berdasarkan $S_{D S}$ dan $S_{D 1}$ untuk Kategori Resiko III dan IV di Kalimantan Selatan

\begin{tabular}{|c|c|c|c|c|c|c|c|c|c|c|c|c|c|}
\hline \multirow{3}{*}{ NO. } & \multirow{3}{*}{ KOTA } & \multicolumn{6}{|c|}{$\begin{array}{l}\text { KATEGORI DESAIN } \\
\text { SEISMIK SNI 1726-2012 }\end{array}$} & \multicolumn{6}{|c|}{$\begin{array}{c}\text { KATEGORI DESAIN SEISMIK } \\
\text { RSNI 1726-2018 }\end{array}$} \\
\hline & & \multicolumn{3}{|c|}{$\begin{array}{l}\text { Kategori } \\
\text { Resiko III }\end{array}$} & \multicolumn{3}{|c|}{$\begin{array}{l}\text { Kategori Resiko } \\
\text { IV }(\text { Ie }=\mathbf{1 , 5})\end{array}$} & \multicolumn{3}{|c|}{$\begin{array}{l}\text { Kategori } \\
\text { Resiko III }\end{array}$} & \multicolumn{3}{|c|}{$\begin{array}{l}\text { Kategori Resiko } \\
\text { IV }(\mathrm{Ie}=\mathbf{1 , 5})\end{array}$} \\
\hline & & SC & SD & SE & $\mathrm{SC}$ & SD & SE & SC & SD & SE & SC & SD & SE \\
\hline 1 & Banjarmasin & A & A & B & A & A & $\mathrm{C}$ & A & B & $\mathrm{C}$ & A & $\mathrm{C}$ & $\mathrm{D}$ \\
\hline 2 & Banjarbaru & A & A & B & A & A & $\mathrm{C}$ & A & B & $\mathrm{C}$ & A & $\mathrm{C}$ & $\mathrm{D}$ \\
\hline 3 & $\begin{array}{l}\text { Kabupaten Tanah } \\
\text { Laut }\end{array}$ & A & A & B & A & A & $\mathrm{C}$ & A & B & $\mathrm{C}$ & A & $\mathrm{C}$ & $\mathrm{D}$ \\
\hline 4 & Kabupaten Banjar & B & B & $\mathrm{C}$ & $\mathrm{C}$ & $\mathrm{C}$ & $\mathrm{D}$ & A & B & $\mathrm{C}$ & A & $\mathrm{C}$ & $\mathrm{D}$ \\
\hline 5 & Kab. Barito Kuala & A & A & B & A & A & $\mathrm{C}$ & A & B & $\mathrm{C}$ & A & $\mathrm{C}$ & $\mathrm{D}$ \\
\hline 6 & Kotabaru (Pulau Laut) & B & B & $\mathrm{C}$ & $\mathrm{C}$ & $\mathrm{C}$ & $\mathrm{D}$ & A & B & $\mathrm{C}$ & A & $\mathrm{C}$ & $\mathrm{D}$ \\
\hline 7 & Kab. Tapin & B & B & $\mathrm{C}$ & $\mathrm{C}$ & $\mathrm{C}$ & $\mathrm{D}$ & B & B & $\mathrm{C}$ & $\mathrm{C}$ & $\mathrm{C}$ & $\mathrm{D}$ \\
\hline 8 & Kab Tanah Bumbu & B & B & $\mathrm{C}$ & $\mathrm{C}$ & $\mathrm{C}$ & $\mathrm{D}$ & B & B & $\mathrm{C}$ & $\mathrm{C}$ & $\mathrm{C}$ & $\mathrm{D}$ \\
\hline 9 & $\begin{array}{l}\text { Kab. Hulu Sungai } \\
\text { Selatan }\end{array}$ & B & $\mathrm{C}$ & $\mathrm{C}$ & $\mathrm{C}$ & $\mathrm{D}$ & $\mathrm{D}$ & B & B & $\mathrm{D}$ & $\mathrm{C}$ & $\mathrm{C}$ & $\mathrm{D}$ \\
\hline 10 & $\begin{array}{l}\text { Kab Hulu Sungai } \\
\text { Tengah }\end{array}$ & B & $\mathrm{C}$ & $\mathrm{D}$ & $\mathrm{C}$ & $\mathrm{D}$ & $\mathrm{D}$ & B & $\mathrm{C}$ & $\mathrm{D}$ & $\mathrm{C}$ & $\mathrm{D}$ & $\mathrm{D}$ \\
\hline 11 & Kab. Kotabaru & B & $\mathrm{C}$ & $\mathrm{D}$ & $\mathrm{C}$ & $\mathrm{D}$ & $\mathrm{D}$ & B & $\mathrm{C}$ & D & $\mathrm{C}$ & $\mathrm{D}$ & $\mathrm{D}$ \\
\hline 12 & $\begin{array}{l}\text { Kab. Hulu Sungai } \\
\text { Utara }\end{array}$ & B & $\mathrm{C}$ & $\mathrm{D}$ & $\mathrm{C}$ & $\mathrm{D}$ & $\mathrm{D}$ & B & $\mathrm{C}$ & $\mathrm{D}$ & $\mathrm{C}$ & $\mathrm{D}$ & $\mathrm{D}$ \\
\hline 13 & Kab. Tabalong & B & $\mathrm{C}$ & $\mathrm{D}$ & $\mathrm{C}$ & $\mathrm{D}$ & $\mathrm{D}$ & B & $\mathrm{C}$ & $\mathrm{D}$ & $\mathrm{C}$ & $\mathrm{D}$ & $\mathrm{D}$ \\
\hline 14 & Pegunungan Meratus & B & $\mathrm{C}$ & $\mathrm{D}$ & $\mathrm{C}$ & $\mathrm{D}$ & $\mathrm{D}$ & $\mathrm{C}$ & $\mathrm{C}$ & $\mathrm{D}$ & $\mathrm{D}$ & $\mathrm{D}$ & $\mathrm{D}$ \\
\hline
\end{tabular}


Hasil akhir perbandingan KDS untuk kelas situs tanah SC, SD dan SE lebih dipengaruhi oleh nilai $S_{D 1}$. Pada struktur dengan kategori resiko I (bangunan dengan resiko rendah terhadap jiwa manusia) dan Kategori resiko II (Semua struktur yang tidak termasuk kategori resiko I,IIIdan IV), untuk empat kota (Banjarmasin, Banjarbaru, Kab. Tanah Laut dan Kab. Barito Kuala) mengalami peningkatan KDS pada situs tanah SD dari A menjadi B dan situs tanah SE dari B menjadi C. Pada Kab Banjar dan Kotabaru (Pulau Laut) mengalami penurunan KDS pada situs tanah SC dari B menjadi A. Pada Kab. Hulu Sungai Selatan mengalami penurunan KDS pada situs tanah SD dari $\mathrm{C}$ menjadi $\mathrm{B}$ dan terjadi peningkatan pada situs tanah SE dari $\mathrm{C}$ menjadi D. Pada pegunungan meratus mengalami peningkatan KDS pada situs tanah SC dari B menjadi C.

Pada struktur dengan kategori resiko III (bangunan dengan resiko tinggi terhadap jiwa manusia dan Semua struktur yang tidak termasuk kategori resiko IV), untuk empat kota (Banjarmasin, Banjarbaru, Kab. Tanah Laut dan Kab. Barito Kuala) mengalami peningkatan KDS pada situs tanah SD dari A menjadi B dan situs tanah SE dari A menjadi C. Pada Kab Banjar dan Kotabaru (Pulau Laut) mengalami penurunan KDS pada situs tanah SC dari B menjadi A. Pada Kab. Hulu Sungai Selatan mengalami penurunan KDS pada situs tanah SD dari $\mathrm{C}$ menjadi $\mathrm{B}$ dan terjadi peningkatan pada situs tanah SE dari $\mathrm{C}$ menjadi D. Pada pegunungan meratus mengalami peningkatan KDS pada situs tanah SC dari B menjadi C.

Pada struktur dengan Kategori resiko IV (bangunan dengan resiko tinggi terhadap jiwa manusia dan ditunjukkan sebagai fasilitas penting), untuk empat kota (Banjarmasin, Banjarbaru, Kab. Tanah Laut dan Kab. Barito Kuala) mengalami peningkatan KDS pada situs tanah SD dari A menjadi $\mathrm{C}$ dan situs tanah SE dari C menjadi D. Pada Kab Banjar dan Kotabaru (Pulau Laut) mengalami penurunan KDS pada situs tanah SC dari C menjadi A. Pada Kab. Hulu Sungai Selatan mengalami penurunan KDS pada situs tanah SD dari D menjadi C. Pada pegunungan meratus mengalami peningkatan KDS pada situs tanah SC dari C menjadi D.

\section{KESIMPULAN}

Berdasarkan hasil analisis maka dapat disimpulkan bahwa:

1. Berdasarkan peta gempa Indonesia 2017, zona percepatan Spektrum Respons 0.2 detik $\mathrm{MCE}_{\mathrm{R}}$ pada daerah Kalimantan Selatan mengalami perubahan, spektrum nilai Ss dari $0,05 \mathrm{~g}$ sampai dengan $0,4 \mathrm{~g}$ dimana nilai Ss terbesar berada di daerah pegunungan meratus dan sekitarnya.

2. Berdasarkan peta gempa Indonesia 2017 didapatkan terjadi penurunan rasio nilai Ss pada Kab. Tabalong dan peningkatan nilai Ss terbesar pada daerah pegunungan meratus dan Kab. Tapin.

3. Pada Spektrum Respons Perioda Pendek 0,2 detik ( $\left.S_{\text {DS }}\right)$ pada semua kota di kalimantan selatan terjadi penurunan rasio berdasarkan kelas situs, dengan nilai kelas situs tanah keras (SC) lebih besar dari kelas situs tanah lunak (SE). Sedangkan sebaliknya dari Spektrum Respons Perioda 1-detik (SD1) terjadi peningkatan rasio berdasarkan kelas situs, dengan nilai kelas situs tanah lunak (SE) lebih besar dari pada kelas situs tanah keras (SC).

4. Struktur bangunan dengan kategori resiko IV didapati memiliki kategori desain seismik tertinggi yaitu KDS D Pada Situs Tanah Keras (Sc) terjadi pada daerah yang berada dalam peta zona gempa Ss senilai 0,3 s.d 0,4g; KDS D Pada Situs Tanah Sedang(SD) terjadi pada daerah yang berada dalam peta zona gempa Ss senilai 0,25 s.d 0,4g; KDS D Pada Situs Tanah Lunak (SE) terjadi pada daerah yang berada dalam peta zona gempa Ss senilai 0,05 s.d $0,4 \mathrm{~g}$

5. Karena telah terjadi peningkatan percepatan batuan akibat dari pergeseran lempengan batuan selama beberapa tahun terakhir, sehingga menyebabkan perubahan zona gempa khususnya untuk daerah Kalimantan Selatan. Maka penggunaan beban gempa seismik pada desain struktur 
dikalimantan selatan menjadi sangat penting untuk meningkatkan keamanan bangunan dari bencana gempa, perencanaan tata ruang, kesiapsiagaan, pembuatan peta risiko dan prioritas mitigasi bahaya gempa.

\section{DAFTAR RUJUKAN}

ASCE/SEI 7-16. Minimum Design Loads and Associated Criteria for Buildings and Other Structures, American Society of Civil Engineers, VA.

Irsyam, Masyhur et all. 2018. Peta Gempa, Perkembangan Dan Aplikasinya Untuk Perancangan Struktur Dan Infrastruktur Tahan Gempa Indonesia. Seminar Nasional Teknik Sipil 2018. Bandung.
Pusat Studi Gempa Nasional. 2017. Peta Sumber dan Bahaya Gempa Indonesia Tahun 2017. Pusat Litbang Perumahan dan Pemukiman, Bandung.

Sengara, I Wayan. 2018. Rekayasa Kegempaan dan Mitigasi Bencana Gempa. Workshop Konstruksi Indonesia. Jakarta.

Setiawan, A. 2016. Perancangan Struktur Beton Bertulang Berdasarkan SNI 2847:2013. Penerbit Erlangga.

SNI 1726:2012. Tata cara perencanaan ketahanan gempa untuk struktur bangunan gedung dan non gedung, Badan Standarisasi Nasional, Jakarta.

Sutjipto, Suradjin dan Sumeru, Indrawati. 2018. Spektrum Respons Desain RSNI 1726:2018 Berdasarkan Peta Gempa Indonesia 2017. Jakarta. 